\title{
Effect of plasma isolated Orexin-A on the regulation of metabolites in male rats
}

\author{
R.F. Jasim ${ }^{1}$ and T.A. Allwsh ${ }^{2}(0$ \\ ${ }^{1}$ Department of chemistry, Collage of Education for Girls, ${ }^{2}$ Department of chemistry, Collage of Science, University of Mosul, \\ Mosul, Iraq
}

\begin{tabular}{l} 
Article information \\
\hline Article history: \\
Received April 24, 2020 \\
Accepted July 14, 2020 \\
Available online June 23, 2021 \\
\hline Keywords: \\
Cholesterol \\
Hyperlipidemic rats \\
Hypocretin \\
Orexin-A \\
OXA purification \\
\hline
\end{tabular}

Correspondence:

R.F. Jasim

ra.fadhel@uomosul.edu.iq

\begin{abstract}
This research includes the isolation and purification of Orexin-A from the plasma of healthy human via various biochemical techniques, it was proposed the therapeutic role of orexin on hyperlipidemia and lipid peroxidation and it has been suggested to study the effect of isolated orexin A on the metabolism of lipids and glucose in normal and hyperlipidemic rats, a high level of orexin-A had been found only in second peak (B) isolated by gel filtration chromatography (using Sephadex G-50) and showed (34.5) fold of purification, also, the effect of isolated orexin-A on some clinical parameters had been studied in normal and hyperlipidemic male rats. The rats were injected intraperitoneally with orexin-A at a dose of $1 \mu \mathrm{mol} / \mathrm{kg}$ of body weight/day for one month. The results, obtained before treatment and after two and four weeks of treatment, had been showing a significant decrease in the concentration of total cholesterol, triglycerides, low and very low-density lipoprotein cholesterol, glucose, malondialdehyde and hyperinsulinemia, while there was a significant increase in the concentration of high-density lipoprotein cholesterol in normal and hyperlipidemic rats. It was concluded that orexin-A had an important role in regulating the metabolism of glucose and lipids, treatment of hyperinsulinemia and insulin resistance, and decreasing lipid peroxidation in normal and hyperlipidemic rats.
\end{abstract}

DOI: 10.33899/ijvs.2020.127001.1429, (92021, College of Veterinary Medicine, University of Mosul.

This is an open access article under the CC BY 4.0 license (http://creativecommons.org/licenses/by/4.0/).

\section{Introduction}

Orexin is a pair of neuropeptides (Orexin-A and OrexinB) derived mainly from neurons distributed in the lateral hypothalamus (LH) (1). In 1998, two researcher's groups discovered the new peptides in the lateral hypothalamus of the rat brain (2). One group of researchers named it "Hypocretin" derived from the hypothalamus, based on its anatomic location and the amino acid sequence similar to the gut hormone, secretin. Another group called it "Orexin" came from orexis, the Greek word meaning appetite (3). There are two type of orexin: Orexin-A (OXA), 33-amino acid, molecular mass $3562 \mathrm{Da}$, contains 4 Cys residues which form two intra-chain disulfide, and has identical sequences in human, rat, mouse, and cow $(4,5)$. Orexin-B
(OXB), 28-amino acid, molecular mass $2937 \mathrm{Da}$, is a liner peptide, and human OXB have different sequences that of the rodents (6). Orexin-A and -B initially identified as endogenous ligands for orphan G-protein coupled receptors (GPCRs) OX1R and OX2R (7). The widespread of orexin neurons and receptors in tissues shows the important role of this hormone. OXA controls body weight through regulation of food intake according to the levels of plasma fuel to maintain energy homeostasis (3) thus, OXA protects against obesity (8) also OXA has a certain role in the metabolism of glucose, improvement of insulin receptors function, preserving insulin sensitivity, regulating lipid metabolism and controlling sleep-waking cycle $(8,9)$. Orexin-A increases the cytoplasmic calcium $\mathrm{Ca}^{+2}$, Orexin-A initially binds to the receptors which in turn activate G-protein and 
subsequently enhances the influx of $\mathrm{Ca}^{+2}$ through channels of the plasma membrane $(3,10)$. The aim of the research was study the effect of isolated OXA from the human plasma on the metabolism of lipids and glucose in normal and hyperlipidemic rats, since there are a few studies in Iraq about OXA in experimental animals.

\section{Materials and methods}

\section{Samples}

Fresh plasma $(50 \mathrm{ml})$ was obtained from one healthy male person with age (37 years) with the assistance of the blood bank in Mosul city (the plasma was taken ready and frozen).

\section{Organic solvent precipitation}

Cold acetone at $4^{\circ} \mathrm{C}(40: 60 \mathrm{v} / \mathrm{v})$ was used to precipitate proteinous material (11). Cold acetone added to plasma gradually with slowly stirring at $4^{\circ} \mathrm{C}$ for $60 \mathrm{~min}$. The mixture was left for $24 \mathrm{~h}$ in the refrigerator at $4^{\circ} \mathrm{C}$. Cooling centrifuge for 30 minutes at $12000 \mathrm{xg}$ was used to isolate the precipitated protein, which was dissolved in the lowest volume of distilled water. The protein and orexin-A concentration were estimated $(12,13)$. The protein solution then kept in a tight test tube for a subsequent step.

\section{Gel filtration chromatography}

The column used in this technique has a dimension of $2 * 60 \mathrm{~cm}$ and filled with a gel (Sephadex G-50). The protein solution (prepared previously) was applied to this column, and the fractions were collected at a flow rate $58 \mathrm{ml} / \mathrm{h}$. Protein and orexin- A concentration were estimated at each step of isolation.

\section{Lyophilization technique}

Peaks A and B obtained from the column was dried using freeze-drying, which was performed in the department of pathological analysis, technical institute, Northern University in Mosul.

\section{Orexin A assay}

Orexin-A level determined by a competitive-enzyme linked immunosorbent assay (ELISA) technique (12) using Elabscience biotechnology, Inc. kit (USA). This assay performed in an immunity laboratory in Al-Salam hospital in Mosul city.

\section{Determination of protein concentration:}

Protein concentration used standard bovine serum albumin by modified Lowry method (13).

\section{The animals}

Albino rats were obtained from the Animal House, College of Veterinary Medicine, University of Mosul. Twenty fourth healthy male rats with age $10 \pm 1$ weeks and weight 200-250 g were divided into four groups (6 each), housed in cages under standard environmental conditions with providing water and pelleted food ad libitum.

\section{Induction of hyperlipidemia: High fat diet}

The high-fat diet was prepared by adding five grams of cholesterol, $1 \mathrm{~g}$ of Cholic acid, $10 \mathrm{ml}$ of coconut oil, $1 \mathrm{~kg}$ of standard diet (14). Rats fed on the high-fat diet for 14 weeks and lipid profile was determined every week.

\section{Experimental design}

The dose used for intraperitoneally injection of isolated orexin-A hormone was $1 \mu \mathrm{mol} / \mathrm{kg}$ bw/d (15). The rats were divided randomly into four groups, each contained six rats and all groups were treated for one month. Control group (CG), the first group was normal rats fed on a standard diet and injected intraperitoneally with physiological saline solution. Normal group with Orexin- A (NGO), the second group was normal rats fed on a standard diet and injected intraperitoneally with isolated Orexin-A (peak B). Hyperlipidemic group (HG), the third group was fed on a high-fat diet and after induction of hyperlipidemia; it was injected intraperitoneally with physiological saline solution and served as control hyperlipidemic group. Hyperlipidemic group with orexin A (HGO), the fourth group was fed on a high-fat diet and after induction of hyperlipidemia; it was injected with isolated Orexin-A (peak B).

\section{Collection of blood}

The Blood samples were collected from the four groups after fasting for $16 \mathrm{~h}$ using a capillary tube without anticoagulant via the orbital sinus puncture technique. Serum separated and used to estimate the following biochemical analysis (16).

\section{Biochemical analysis}

Collected sera were being aliquot to several aliquots for biochemical analysis, which includes the following tests; Fasting blood glucose was determined immediately using the Spinreact kit (Spain) by spectrophotometer at $500 \mathrm{~nm}$ (17). Insulin concentration was measured by Monobind ELISA kit USA (18). Total cholesterol was determined by enzymatic colorimetric method using the BIOLABO kit (France) by spectrophotometer at $500 \mathrm{~nm}$ (19). Triglycerides TG were determined by enzymatic colorimetric method using the BIOLABO kit (France) by spectrophotometer at $500 \mathrm{~nm}$ (20). Very low-density lipoprotein-cholesterol (VLDL-C) was calculated using the equation: VLDL-C $[(\mathrm{mmol} / \mathrm{L})=\mathrm{TG}(\mathrm{mmol} / \mathrm{L}) / 2.2](21)$. High-density lipoprotein-cholesterol (HDL-C) was estimated by precipitation method using the BIOLABO kit (France) by spectrophotometer at $500 \mathrm{~nm}$ (22). Low-density lipoprotein-cholesterol (LDL-C) was calculated using Friedewald equation $[\mathrm{LDL}-\mathrm{C}(\mathrm{mmol} / \mathrm{L})=$ Total cholesterolHDL-C-TG/2.2] (17). Malondialdehyde (MDA) determined 
using Thiobarbituric acid test (23), MDA react with Thiobarbituric acid to produce colored compound measured at $532 \mathrm{~nm}$. Aspartate Aminotransferase (AST) and Alanine Aminotransferase (ALT) activity were determined by the Reflotron Plus system using reflation strips $(24,25)$. Uric acid was determined by enzymatic colorimetric method using the Spinreact kit (Spain) by spectrophotometer at 520 nm (26).

\section{Statistical analysis}

Data were analyzed by SPSS software and expressed as mean \pm SE. To compare between more than two treatments, one-way ANOVA and Duncan-test were used, and the results considered to be significant at $\mathrm{P} \leq 0.05$ (27).

\section{Results}

\section{Isolation and purification of orexin A from human plasma}

The protein precipitate solution obtained from plasma by cold acetone contains a level of orexin-A $402.7 \mathrm{pg} / \mathrm{ml}$ compared to plasma $313.9 \mathrm{pg} / \mathrm{ml}$, while there wasn't any level of orexin-A in the filtrate thus, it was neglected.

\section{The gel filtration chromatography technique}

Gel filtration chromatography was used to separate the protein precipitate solution obtained by precipitation method using cold acetone from human plasma. As shown in, the elution of proteinous precipitate solution shows two peaks A and B. he elution volume of peaks A and B were $71.1,155.1 \mathrm{ml}$ respectively. Only the obtained peak B has a high level of orexin-A. The results in a table 1 showed purification steps of orexin-A hormone. The level of orexinA was increased from $313.9 \mathrm{pg} / \mathrm{ml}$ in plasma to $402.7 \mathrm{pg} / \mathrm{ml}$ in protein precipitate solution to $614.3 \mathrm{pg} / \mathrm{ml}$ in peak B, while the protein concentration was decreased (Figure 1) (Table 1)

Effect of isolated orexin A on some clinical parameters in normal and hyperlipidemic male rats

The intraperitoneal injection of $1 \mu \mathrm{mol} / \mathrm{kg} \mathrm{b.w.} \mathrm{/day} \mathrm{of}$ isolated orexin-A in normal and hyperlipidemic rats showed the following results:

\section{The effect of orexin $A$ on lipid profile and malondialdehyde}

The results in tables 2 and 3 showed that there was a significant decrease in TC, TG, VLDL-C and LDL-C concentration in NGO compared to $\mathrm{CG}$ after 4 weeks and in HGO compared to HG after 2 and 4 weeks of treatment.

On the other hand, the results in a table 4 showed a significant increase in HDL-C concentration in NGO compared to $\mathrm{CG}$ after 2 and 4 weeks and in HGO compared with $\mathrm{HG}$ after 4 weeks of treatment. Also the results showed a significant decrease in malondialdehyde concentration in NGO compared to CG after 4 weeks and in HGO compared to $\mathrm{HG}$ after 2 and 4 weeks of treatment (Table 4 ).

Table 1: Partial purification of orexin A in human plasma

\begin{tabular}{lcccccc}
\hline Purification Steps & $\begin{array}{c}\text { Volume } \\
(\mathrm{ml})\end{array}$ & $\begin{array}{c}\text { Total protein } \\
(\mathrm{mg})\end{array}$ & $\begin{array}{c}\text { Total con. } \\
\text { of OXA }(\mathrm{pg})\end{array}$ & $\begin{array}{c}\text { Total specific Con. } \\
\text { of OXA }(\mathrm{pg} / \mathrm{mg})\end{array}$ & Recovery \% & $\begin{array}{c}\text { Times of } \\
\text { purification }\end{array}$ \\
\hline $\begin{array}{l}\text { Plasma } \\
\text { Proteinous }\end{array}$ & 50 & 410 & 15695 & 38.2 & 100 & 1 \\
$\begin{array}{l}\text { precipitate solution } \\
\begin{array}{l}\text { Gel filtration } \\
\text { /Sephadex G-50 } \\
\text { (peak B) after }\end{array}\end{array}$ & 35 & 214 & 14096 & 65.8 & 89.8 & 1.7 \\
Lyophilizer & 20 & 9.3 & 12286 & 1321.1 & 78.2 & 34.5 \\
\hline
\end{tabular}

Table 2: Effect of isolated orexin-A on TC and TG concentration after 2 and 4 weeks of treatment

\begin{tabular}{|c|c|c|c|c|c|c|}
\hline \multirow{3}{*}{ Groups } & \multicolumn{3}{|c|}{ TC conc. $(\mathrm{mmol} / \mathrm{L})$ Mean \pm S.E } & \multicolumn{3}{|c|}{ TG conc. $(\mathrm{mmol} / \mathrm{L})$ Mean \pm S.E } \\
\hline & \multirow{2}{*}{$\begin{array}{l}\text { Pre-treatment } \\
\text { zero time }\end{array}$} & \multicolumn{2}{|c|}{ Post-treatment } & \multirow{2}{*}{$\begin{array}{l}\text { Pre-treatment } \\
\text { zero time }\end{array}$} & \multicolumn{2}{|c|}{ Post-treatment } \\
\hline & & Week 2 & Week 4 & & Week 2 & Week 4 \\
\hline CG & $4.0 \pm 0.26$ & $3.92 \pm 0.21$ & $3.99 \pm 0.19$ & $1.92 \pm 0.06$ & $1.79 \pm 0.18$ & $1.80 \pm 0.14$ \\
\hline NGO & $3.98 \pm 0.1$ & $3.33 \pm 0.26$ & $3.16 \pm 0.22 \mathrm{~b}$ & $1.97 \pm 0.21$ & $* 1.41 \pm 0.09$ & $* 1.11 \pm 0.02 \mathrm{~b}$ \\
\hline HG & $5.01 \pm 0.29 \mathrm{~b}$ & $* 6.0 \pm 0.18 \mathrm{~b}$ & $* 7.01 \pm 0.3 \mathrm{c}$ & $2.46 \pm 0.02 \mathrm{~b}$ & $* 2.85 \pm 0.06 \mathrm{c}$ & $* 3.02 \pm 0.13 \mathrm{c}$ \\
\hline $\mathrm{HGO}$ & $5.14 \pm 0.26 \mathrm{~b}$ & $* 3.96 \pm 0.26$ & $* 3.05 \pm 0.14 \mathrm{~b}$ & $2.69 \pm 0.07 \mathrm{~b}$ & $* 2.23 \pm 0.04 \mathrm{~b}$ & $* 1.92 \pm 0.1$ \\
\hline
\end{tabular}

* indicate significant differences at $(\mathrm{p} \leq 0.05)$ between time zero and treatment groups.

Small different letters indicate significant differences between control and treatment groups at $(\mathrm{P} \leq 0.05), \mathrm{SE}$ : stander error. 


\section{The effect of Orexin-A on Blood glucose (BG) and insulin concentration}

The results in a table 5 showed a significant decrease in glucose concentration in NGO compared with CG and in HGO compare with HG after 2 and 4 weeks of treatment. While, there was a non-significant increase in insulin concentration in NGO, and HG has hyperinsulinemia. Also, there was a significant decrease in insulin at HGO compared to HG after 2 and 4 weeks of treatment.

\section{The effect of Orexin-A on AST and ALT activity and uric acid concentration}

As shown in a tables 6 and 7 there was a non-significant difference in AST, ALT activity, and uric acid concentration at NGO and HGO after treatment with Orexin-A.

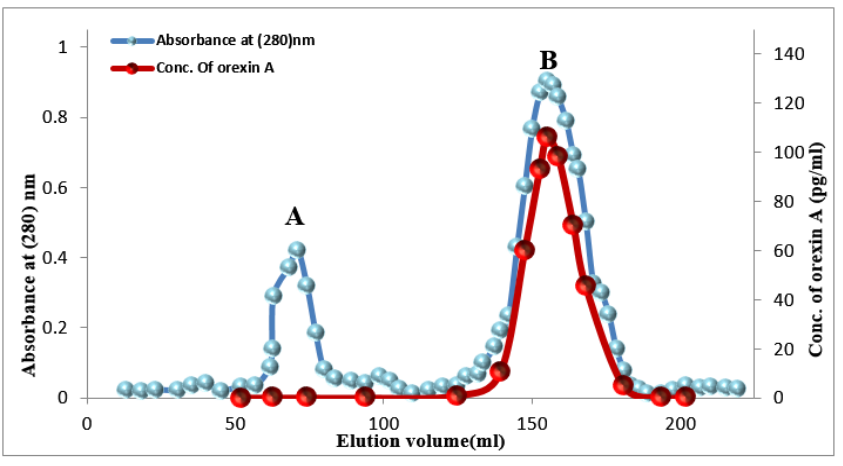

Figure 1: Elution of protein precipitate solution obtained from plasma by cold acetone on Sephadex G-50. The dimension of the column is $2 \times 60 \mathrm{~cm}$ at the flow rate is 58 $\mathrm{ml} / \mathrm{h}$.

Table 3: Effect of isolated orexin-A on VLDL-C and LDL-C concentration after 2 and 4 weeks of treatment

\begin{tabular}{|c|c|c|c|c|c|c|}
\hline \multirow{3}{*}{ Groups } & \multicolumn{3}{|c|}{ VLDL-C conc. $(\mathrm{mmol} / \mathrm{L})$ Mean \pm S.E } & \multicolumn{3}{|c|}{ LDL-C conc. $(\mathrm{mmol} / \mathrm{L})$ Mean \pm S.E } \\
\hline & \multirow{2}{*}{$\begin{array}{l}\text { Pre-treatment } \\
\text { zero time }\end{array}$} & \multicolumn{2}{|c|}{ Post-treatment } & \multirow{2}{*}{$\begin{array}{l}\text { Pre-treatment } \\
\text { zero time }\end{array}$} & \multicolumn{2}{|c|}{ Post-treatment } \\
\hline & & Week 2 & Week 4 & & Week 2 & Week 4 \\
\hline CG & $0.86 \pm 0.02$ & $0.8 \pm 0.08$ & $0.81 \pm 0.06$ & $1.85 \pm 0.27$ & $1.91 \pm 0.3$ & $1.94 \pm 0.17$ \\
\hline NGO & $0.88 \pm 0.09$ & $* 0.63 \pm 0.04$ & $* 0.5 \pm 0.01 \mathrm{~b}$ & $1.69 \pm 0.15$ & $1.16 \pm 0.27$ & $0.92 \pm 0.22 \mathrm{~b}$ \\
\hline HG & $1.11 \pm 0.01 \mathrm{~b}$ & $* 1.28 \pm 0.02 \mathrm{c}$ & $* 1.36 \pm 0.06 \mathrm{c}$ & $2.97 \pm 0.29 \mathrm{~b}$ & $* 3.91 \pm 0.19 \mathrm{~b}$ & $* 4.91 \pm 0.26 \mathrm{c}$ \\
\hline HGO & $1.21 \pm 0.03 \mathrm{~b}$ & $* 1.01 \pm 0.02 \mathrm{~b}$ & $* 0.86 \pm 0.04$ & $3.02 \pm 0.25 \mathrm{~b}$ & $* 1.96 \pm 0.27$ & $* 1.06 \pm 0.16 \mathrm{~b}$ \\
\hline
\end{tabular}

* indicate significant differences at $(\mathrm{p} \leq 0.05)$ between time zero and treatment groups.

Small different letters indicate significant differences between control and treatment groups at $(\mathrm{P} \leq 0.05)$.

Table 4: Effect of isolated orexin-A on HDL-C and MDA concentrations after 2 and 4 weeks of treatment

\begin{tabular}{|c|c|c|c|c|c|c|}
\hline \multirow{3}{*}{ Groups } & \multicolumn{3}{|c|}{ HDL-C conc. $(\mathrm{mmol} / \mathrm{L})$ Mean \pm S.E } & \multicolumn{3}{|c|}{ MDA $(\mu \mathrm{mol} / \mathrm{L})$ con. Mean \pm S.E } \\
\hline & \multirow{2}{*}{$\begin{array}{l}\text { Pre-treatment } \\
\text { zero time }\end{array}$} & \multicolumn{2}{|c|}{ Post-treatment } & \multirow{2}{*}{$\begin{array}{l}\text { Pre-treatment } \\
\text { zero time }\end{array}$} & \multicolumn{2}{|c|}{ Post-treatment } \\
\hline & & Week 2 & Week 4 & & Week 2 & Week 4 \\
\hline CG & $1.29 \pm 0.11$ & $1.21 \pm 0.09$ & $1.23 \pm 0.07$ & $1.83 \pm 0.16$ & $1.61 \pm 0.26$ & 0.12 \\
\hline NGO & $1.22 \pm 0.01$ & $* 1.54 \pm 0.02 \mathrm{c}$ & $* 1.73 \pm 0.02 \mathrm{c}$ & $1.26 \pm 0.16$ & $* 0.87 \pm 0.06$ & $* 0.73 \pm 0.02 \mathrm{~b}$ \\
\hline HG & $0.92 \pm 0.01 \mathrm{~b}$ & $* 0.8 \pm 0.01 \mathrm{~b}$ & $* 0.73 \pm 0.01 \mathrm{~b}$ & $2.74 \pm 0.19 \mathrm{~b}$ & $* 3.58 \pm 0.22 \mathrm{~b}$ & $* 4.35 \pm 0.19 \mathrm{c}$ \\
\hline $\mathrm{HGO}$ & $0.9 \pm 0.01 \mathrm{~b}$ & $* 0.98 \pm 0.02 \mathrm{~b}$ & $* 1.13 \pm 0.01$ & $2.65 \pm 0.11 \mathrm{~b}$ & $* 1.85 \pm 0.16$ & $* 1.50 \pm 0.13$ \\
\hline
\end{tabular}

* indicate significant differences at $(\mathrm{p} \leq 0.05)$ between time zero and treatment groups.

Small different letters indicate significant differences between control and treatment groups at $(\mathrm{P} \leq 0.05)$.

Table 5: Effect of isolated orexin-A on blood glucose and insulin concentration after 2 and 4 weeks of treatment

\begin{tabular}{|c|c|c|c|c|c|c|}
\hline \multirow{3}{*}{ Groups } & \multicolumn{3}{|c|}{ BG con. $(\mathrm{mmol} / \mathrm{L})$ Mean \pm S.E } & \multicolumn{3}{|c|}{ Insulin con. $(\mu \mathrm{IU} / \mathrm{ml})$ Mean \pm S.E } \\
\hline & \multirow{2}{*}{$\begin{array}{l}\text { Pre-treatment } \\
\text { zero time }\end{array}$} & \multicolumn{2}{|c|}{ Post-treatment } & \multirow{2}{*}{$\begin{array}{l}\text { Pre-treatment } \\
\text { zero time }\end{array}$} & \multicolumn{2}{|c|}{ Post-treatment } \\
\hline & & Week 2 & Week 4 & & Week 2 & Week 4 \\
\hline CG & $5.83 \pm 0.11$ & $5.91 \pm 0.11$ & $5.96 \pm 0.15$ & $12.66 \pm 0.45$ & $12.85 \pm 0.53$ & $13.0 \pm 0.48$ \\
\hline NGO & $5.62 \pm 0.14$ & $* 4.98 \pm 0.20 \mathrm{~b}$ & $* 4.68 \pm 0.13 \mathrm{~b}$ & $12.96 \pm 0.86$ & $13.19 \pm 0.54$ & $13.22 \pm 016$ \\
\hline HG & $7.47 \pm 0.15 b$ & $* 8.06 \pm 0.13 \mathrm{c}$ & $* 8.80 \pm 0.16 \mathrm{c}$ & $17.15 \pm 0.78 b$ & $18.52 \pm 0.29 \mathrm{~b}$ & $* 21.25 \pm 0.9 \mathrm{~b}$ \\
\hline $\mathrm{HGO}$ & $7.75 \pm 0.09 \mathrm{~b}$ & $* 6.12 \pm 0.05$ & $* 5.07 \pm 0.10 \mathrm{~b}$ & $16.96 \pm 0.27 \mathrm{~b}$ & $* 14.79 \pm 0.61$ & $* 14.03 \pm 0.59$ \\
\hline
\end{tabular}

* indicate significant differences at $(\mathrm{p} \leq 0.05)$ between time zero and treatment groups.

Small different letters indicate significant differences between control and treatment groups at $(\mathrm{P} \leq 0.05)$. 
Table 6: Effect of isolated Orexin-A on AST and ALT activity after 2 and 4 weeks of treatment

\begin{tabular}{|c|c|c|c|c|c|c|}
\hline \multirow{3}{*}{ Groups } & \multicolumn{3}{|c|}{ AST activity (U/L) Mean \pm S.E } & \multicolumn{3}{|c|}{ ALT activity (U/L) Mean \pm S.E } \\
\hline & \multirow{2}{*}{$\begin{array}{l}\text { Pre-treatment } \\
\text { zero time }\end{array}$} & \multicolumn{2}{|c|}{ Post-treatment } & \multirow{2}{*}{$\begin{array}{l}\text { Pre-treatment } \\
\text { zero time }\end{array}$} & \multicolumn{2}{|c|}{ Post-treatment } \\
\hline & & Week 2 & Week 4 & & Week 2 & Week 4 \\
\hline CG & $10.57 \pm 0.89$ & $11.07 \pm 0.69$ & $10.86 \pm 0.83$ & $6.04 \pm 0.92$ & $6.1 \pm 0.89$ & $5.97 \pm 0.77$ \\
\hline NGO & $10.43 \pm 0.8$ & $10.87 \pm 0.62$ & $9.98 \pm 0.98$ & $5.89 \pm 0.73$ & $5.67 \pm 0.81$ & $5.41 \pm 0.70$ \\
\hline HG & $15.42 \pm 1.17 \mathrm{~b}$ & $19.71 \pm 1.29 \mathrm{~b}$ & $* 20.99 \pm 1.74 \mathrm{~b}$ & $10.2 \pm 0.83 \mathrm{~b}$ & $* 15.62 \pm 1.98 \mathrm{~b}$ & $* 16.02 \pm 1.3 \mathrm{~b}$ \\
\hline HGC & $16.17 \pm 1.62 \mathrm{~b}$ & $15.95 \pm 1.17 \mathrm{~b}$ & $16.11 \pm 1.21 \mathrm{~b}$ & $11.83 \pm 1.29 \mathrm{~b}$ & $11.56 \pm 1.24 \mathrm{~b}$ & $12.0 \pm 1.61 \mathrm{~b}$ \\
\hline
\end{tabular}

* indicate significant differences at $(\mathrm{p} \leq 0.05)$ between time zero and treatment groups.

Small different letters indicate significant differences between control and treatment groups at $(\mathrm{P} \leq 0.05)$.

Table 7: Effect of isolated Orexin-A on uric acid after 2 and 4 weeks of treatment

\begin{tabular}{lccc}
\hline & \multicolumn{2}{c}{ Uric acid con. (mg/dL) Mean \pm S.E } \\
\cline { 2 - 4 } Groups & Pre-treatment & \multicolumn{2}{c}{ Post-treatment } \\
\cline { 2 - 4 } & zero time & Week 2 & Week 4 \\
\hline CG & $1.51 \pm 0.13$ & $1.45 \pm 0.11$ & $1.55 \pm 0.1$ \\
NGO & $1.65 \pm 0.17$ & $1.41 \pm 0.15$ & $1.46 \pm 0.15$ \\
HG & $2.16 \pm 0.23 \mathrm{~b}$ & $2.87 \pm 0.16 \mathrm{~b}$ & $* 3.5 \pm 0.14 \mathrm{~b}$ \\
HGO & $2.88 \pm 0.2 \mathrm{~b}$ & $2.74 \pm 0.24 \mathrm{~b}$ & $2.96 \pm 0.22 \mathrm{~b}$ \\
\hline
\end{tabular}

* indicate significant differences at $(\mathrm{P} \leq 0.05)$ between time zero and treatment groups. Small different letters indicate significant differences between control and treatment groups at $(\mathrm{P} \leq 0.05)$.

\section{Discussion}

The treatment of rat groups with isolated Orexin-A for one month caused a significant decrease in TC, TG, VLDL$\mathrm{C}$ and LDL-C concentration, these results are agreement with (28). This might be due to the role of OXA in activation of AMP-activity protein kinase (AMPK) by increasing the concentration of intracellular calcium $\left(\mathrm{Ca}^{+2}\right)(1,29)$. AMPK inhibits HMG-CoA reductase and acetyl-CoA carboxylase which involved in the synthesis of cholesterol and de novo pathway of fatty acid and TG synthesis respectively (30), or because OXA decreases hormone-sensitive lipase (HSL) and inhibits lipolysis in adipose tissue (31), also OXA increases lipogenesis by decreasing the release of glycerol from adipose tissue and increasing glucose uptake (32). Also, it can be due to that Orexin-A promotes adiponectin secretion which increases LPL activity and VLDL-C receptors and decreases Apo CIII, so increases catabolism of VLDL-C and reduces serum TG (33).

On the other hand, the rats treated with isolated OrexinA showed an increase in concentration of HDL-C and this might be due to that Orexin-A increases LPL activity which in turn increases HDL-C (32), or due to that Orexin-A promotes expression and secretion of adiponectin which correlates positively with HDL-C (34). In addition, there was a significant decrease in malondialdehyde concentration and this agrees with Butterick et al. (35) that Orexin-A decreases lipid peroxidation by its neuroprotective mechanisms due to the induction of the transcription factor hypoxia inducible factor- $1 \alpha(\mathrm{HIF}-1 \alpha)$ in the hypothalamus which decreased lipid peroxidation (36).

Glucose concentration decreased in treated rats and that constant with Skrzypski et al. (34), Orexin-A promotes glucose uptake and synthesis of glycogen in skeletal muscle. Orexin-A suppresses the secretion of glucagon thus, OrexinA regulates the concentration of glucose and dysfunction in Orexin-A is an effective factor in homeostasis of glucose and induce of diabetes (8), while insulin increased slightly in NGO when treated with isolated Orexin-A (34). Feeding with the high-fat diet for long-time might cause hyperinsulinemia in $\mathrm{HG}$, which constant with Barclay et al. (37). High-fat diet can cause reduction in the expression of Orexin-A in the hypothalamus, which exacerbates insulin resistance (3). Furthermore, HGO showed a significant decrease in insulin compared to $\mathrm{HG}$ after treatment and that is in agreement with Kaczmarek et al. (38), Orexin-A decreases hyperinsulinemia, enhancing insulin sensitivity and attenuates apoptosis of pancreatic $\beta$-cells by decrease the activity and production of caspase 3 , which induces $\beta$ cells death (38).

While there were non-significant differences in AST, ALT activity, and uric acid concentration at NGO and HGO after treatment with Orexin-A, and this might be due to the time of treatment that might be not enough or the dose was not sufficient.

\section{Conclusion}

It was concluded that Orexin-A (isolated from human plasma) had an important role in the control of glucose and lipids metabolism, treatment of hyperinsulinemia and increasing insulin sensitivity in normal and hyperlipidemic rats. Orexin-A had a critical role in decreasing lipid peroxidation.

\section{Acknowledgment}

The authors are very grateful to the University of Mosul, College of Science for providing the facilities that helped improve the quality of this research.

\section{Conflict of interests}

The authors declare no conflict of interest. 


\section{Reference}

1. Wang C, Wang Q, Ji B, PanY, Xu C, Cheng B, Bai B, Chen J. The orexin / Receptor system:Molecular mechanism and therapeutic potential for neurological diseases. Front Mol Neurosci. 2018;11(220):1-16. DOI: 10.3389/fnmol.2018.00220

2. Sakurai T, Amemiya A, Ishii M, Matsuzaki I, Chemelli RM. Orexins and orexin receptors: A family of hypothalamic neuropeptides and $\mathrm{g}$ protein-coupled receptors that regulate feeding behavior. Cell.1998;92:573-585. [available at]

3. Jain S, Jain A K. Orexin neuropetides :Physiology and significance in food metabolism. Astro. 2016;3:148- 152. DOI: 10.4103/23490977.201002

4. Khaldi S. Effects of acute heat and oxidative stress on the hepatic expression of orexin and its related receptors. Theses Dissertations. 2016: 1849. [available at]

5. Chieffi S, Carotenuto M, Monda V, Valenzano A, Villano I, Precenzano F. Orexin system :The key for a healthy life. Front Physio. 2017;8(357): 1-9. DOI: $10.3389 /$ fphys.2017.00357

6. Graybill NL, Weissig V. A review of orexin's unprecedented potential as a novel highly-specific treatment for various localized and metastatic cancers. SAGE Open Med. 2017;5:1-9. DOI: 10.1177/2050312117735774

7. Becquet L, Abad C, Leclercq M, Miel C, Jean L, Riou G, Couvineau A, Boyer O, Tan Y-V. Systemic administration of orexin A ameliorates established experimental autoimmune encephalomyelitis by diminishing neuroinflammation. J Neuroinflammation. 2019;16(64):112. [available at]

8. Alizadeh AA, Rahmani-nia F, Mohebbi H, Zakerkish M. Acute aerobic exercise and plasma levels of orexin a, insulin, glucose, and insulin resistance in males with type 2 diabetes. Jundishapur J Health Sci. 2016;8(1):e32217. DOI: 10.17795/ijhs-32217

9. Messina G, Dalia C, Tafuri D, Monda V, Palmieri F, Dato A, Russo A, Russo L, De Blasio S, Messina A, De Luca V, Chieffi S, Monda M. Orexin system modulates resting energy expenditure, autonomic nervous system and cardiovascular disease in menopause. J Anesth Clin Res. 2014;5(11):472. DOI: 10.4172/2155-6148.1000472

10. Liu L, Wang Q, Liu A, Lan X, Huang Y, Zhao Z. Physiological implications of orexins/hypocretins on energy metabolism and adipose tissue development. ACS Omega. 2020;5(1):547-555. [available at]

11. Robyt FJ, White JB. Biochemical techniques theory and practice USA: Books Cole Publishing Co; 1987. [available at]

12. Tsuchimine S, Hattori K, Ota M, Hidese S, Teraishi T, Sasayama D, Hori H, Noda T, Yoshida S, Yoshida F, Kunugi H. Reduced plasma orexin-a levels in patients with bipolar disorder. Neuropsychiatr Dis Treat. 2019;15:2221-2230. [available at]

13. Schacterle GR, Pollack RL. A simplified method for the quantitatiue assay of small amounts of protein biological material. J Anal Biochem. 1973;51:654-655. DOI: 10.1016/0003-2697(73)90523-X

14. Rachh PR, Rachh MR, Ghadiya, Modi DC, Patel MN Antihyperlipidemic activity of gymenma syslvestre r. br. leaf extract on rats feed with high cholesterol diet. Inter J Pharma. 2010;6(2):138141. DOI: $10.3923 /$ iip.2010.138.14

15. Blais A, Drouin G, Chaumontet C, Voisin T, Couvelard A, Even PC, Couvineau A. Impact of orexin-a treatment on food intake, energy metabolism and body weight in mice. PLoS ONE. 2017;12(1):1-14 DOI: 10.1371 /journal.pone. 0169908

16. Al-abdaly1 YZ, Saeed MG, Al-Hashemi HM. Effect of methotrexate and aspirin interaction and its relationship to oxidative stress in rats. Iraqi J Vet Sci. 2021;35(1):151-156. DOI 10.33899/ijvs.2020.126490.1335

17. Burtis CA, Ashwood ER, Bruns DE. Tietz textbook of clinical chemistry and molecular diagnostics. $4^{\text {th }}$ ed. USA: Elsevier Saunders; 2005. [available at]

18. Sacks BD. Tietz textbook of clinical chemistr. $2^{\text {nd }}$ ED. Philadelphia: Saunders Co; 1994. [available at]

19. Maty HN. Effect of supplementation of rumen protected methionine and lysine on some physiological aspects of fattening calves. Iraqi J Vet Sci. 2021;35(1):177-181. DOI: 10.33899/ijvs.2020.126580.1344

20. Hassan MG, Abdullah TA. The effect of Propolis addition to broiler feeds on some blood biochemical parameters and intestinal flora. Iraqi J Vet Sci.2020;24(1):29-35. DOI: 10.33899/ijvs.2019.125483.1015

21. Fischbach F. A manual of Laboratory and Diagnostic Tests. $7^{\text {th }}$ ed USA: Lippincott Williams and Wilkins; 2003. 472 p. [available at]

22. Jameel AH, Mohammed MJ, Mahdi MS, Thal KM. Physiological effects of lactic acid bacteria against melamine induced toxicity in female albino rats. Iraqi J Vet Sci. 2021;35(1):1-7. DOI: 10.33899/ijvs.2020.126183.1259

23. Al-Bajar SHA, Al- Akash MA, Ismail HKh. Experimental detection of antioxidant and atherogenic effects of grapes seeds extracts in rabbits. Iraqi J Vet Sci. 2019;33(2):243-249. DOI: 10.33899/ijvs.2019.162881

24. AL-Mashhadani ZI, Mukhlis AJA, A-Razaq AAS. Estimation of ALP, GPT and GOT activities in iraqi patients female with breast cancer. Ibn Al Haitham J for Pure and Appl Sci. 2012;25(1):1-3. [available at]

25. Koller PU, Tritschler W, Carstensen CA. Interference studies on the R eflotron system. Lab Med. 1989;13:399-402. [available at]

26. Fossati P, Prencipe L, Berti G. Use of 3,5-dichloro-2hydroxybenzenesulfonic acid/4-aminophenazone chromogenic system in direct enzymic assay of uric acid in serum and urine. Clin Chem. 1980;26:227-231. DOI: 10.1093/clinchem/26.2.0227

27. Kirkwood BR. Essentials of Medical Statistics. 1st Ed. Black well Scientific Publication, Oxford;1988:43-56. [available at]

28. Abd El-Ghany MA, Hanaa FE, Nagib RM, Hagar ME. Effect of Orexin drug and some minerals on rats exposed to obesity and ALzheimer disease. WJPPS. 2017;6(1):21-37. DOI: 10.20959/wjpps20171-8217

29. Wu WN, Wu PF, Zhou J, Guan XL, Zhang Z, Yang YJ, Long LH, Xie $\mathrm{N}$, Chen J, Wang F. Orexin-A activates hypothalamic AMP-activated protein kinase signaling through a $\mathrm{Ca}^{2}{ }_{+}$-dependent mechanism involving voltage-gated L-type calcium channel. Mol Pharmacol. 2013;84(6):879-887. [available at]

30. López M, Nogueiras R, Tena-Sempere M, Dieguez C. Hypothalamic AMPK:A canonical regulator of whole-body energy balance. Nat Rev Endocrinol. 2016;12(7):421-432. DOI: 10.1038/nrendo.2016.67

31. Digby JE, Chen J, Tang JY, Lehnert H, Matthews RN, Randeva HS Orexin receptor expression in human adipose tissue:effects of orexina and orexin-b. J Endocrinol. 2006;191(1):129-36. DOI: $\underline{10.1677 / \text { joe. } 1.06886}$

32. Pruszynska-Oszmalek E, Kolodziejski PA, Kaczmarek P, Sassek M Orexin a but not orexin $\mathrm{b}$ regulates lipid metabolism and leptin secretion in isolated porcine adipocytes. Domest Anim Endocrinol. 2018;63. DOI: 10.1016/j.domaniend.2017.12.003

33. Yanai H, Yoshida H. Beneficial effects of adiponectin on glucose and lipid metabolism and atherosclerotic progression:Mechanisms and perspectives. Int J Mol Sci. 2019;20(1190):1-25. DOI: 10.3390/ijms20051190

34. Skrzypski M, Billert M, Nowak KW, Strowski MZ. The role of orexin in controlling the activity of the adipo-pancreatic axis. J Endocrinol. 2018;238:R95-108. [available at]

35. Butterick TA, Nixon JP, Billington CJ, Kotz CM. Orexin A decreases lipid peroxidation and apoptosis in a novel hypothalamic cell model. Neurosci Lett. 2012;524(1):30-34. DOI: 10.1016/j.neulet.2012.07.002

36. Butterick TA, Billington CJ, Kotz CM Nixon JP. Orexin:Pathways to obesity resistance?. Rev Endocr Metab Disord. 2013;14(4):357-364. DOI: 10.1007/s11154-013-9259-3

37. Barclay JL, Shostak A, Leliavski A, Tsang AH, Jöhren O, MullerFielitz H, Landgraf D, Naujokat N, Van der Horst GTJ, Oster H. Highfat diet-induced hyperinsulinemia and tissue-specific insulin resistance in Cry-deficient mice. Am J Physiol Endocrinol Metab. 2013;304(10):1053-1063. DOI: 10.1152/ajpendo.00512.2012

38. Kaczmarek P, Skrzypski M, Pruszynska-Oszmalek E, Sassek M, Kolodziejski PA, Billert M. Chronic orexin-a (Hypocretin-1) treatment of type 2 diabetic rats improves glucose control and beta-cell functions. JPP. 2017;68(5):669-681. [available at] 


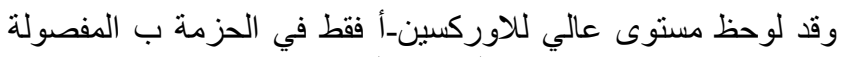

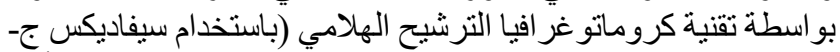

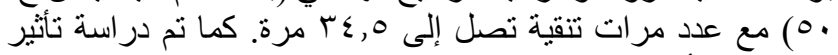

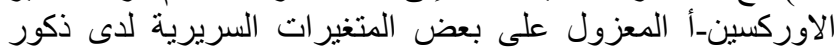

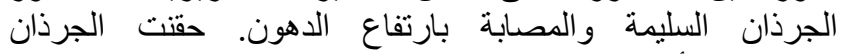

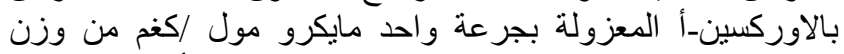

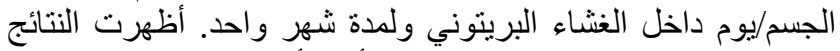

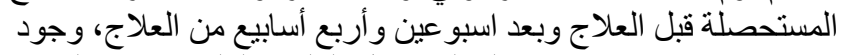

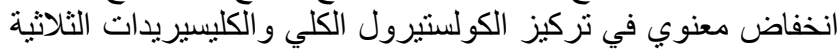

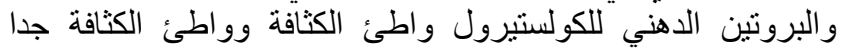

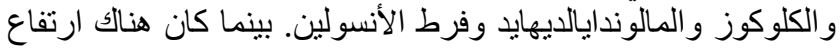

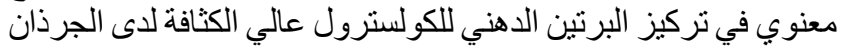

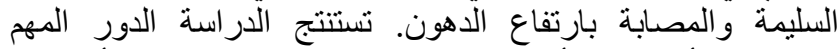

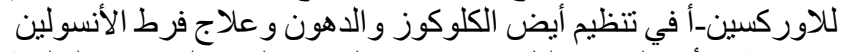

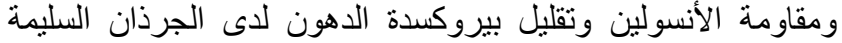

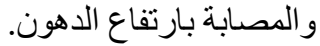

تأثير اوركسين - أ المعزول من البلازما على تتظيم النواتج الأيضية في ذكور الجرذان أنين رنا فاضل جاسم' و ذكرى علي عوش'

'قسم الكيمياء، كلية التربية للبنات، 'ققم الكيمياء، كلبة العلوم، جامعة

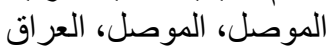

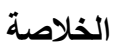

تضمن البحث محاولة عزل وتتقية الاوركسين-أ من بلازما شخص

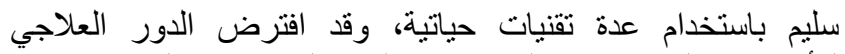

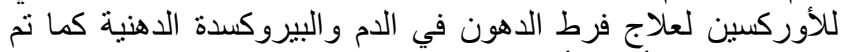

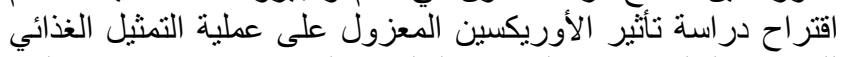
للاهون و الجلوكوز في الجرذان السليمة و المصابة بارتفاع دهون الدئ الدئ 